\title{
ANAYASA MAHKEMELERİ ÖNEMLİ MİDİR? Orta Avrupa'da Anayasa Yargısı ve Demokrasinin Pekişmesi
}

Prof. Dr. Mustafa ERDOĞAN*

\section{GİRIŞ}

Demokrasiye geçişle ilgili literatürde hakim yaklaşım meselenin hukuki olmayan yönleri üzerinde odaklaşmaktır. Hukuki kurumların ve yargının bu sürece katkı yapıp yapmadığı, çoğunlukla siyaset bilimcilerden oluşan demokratikleşme ve demokrasinin pekişmesi araştırmacılarının genellikle daha az ilgisini çekmiştir. Ne var ki, hukuk devletinin etkisi yanında mahkemelerin siyasi sistem içindeki yeri herhangi bir siyasi sistemin doğru incelenmesinden ayrılamaz; "politikanın açıklanması mahkemeleri işin içine katmadıkça eksik kalır."

Genel olarak, "siyasetin hukukileşmesi” denen olgu bir ölçüde modern demokratik siyasetin bir özelliği olmuştur. Bu, modern demokrasilerin esas olarak "anayasal demokrasi" niteliğinde olmalarından kaynaklanmaktadır. Anayasacılık hukukla siyaset arasındaki ilişkinin belli bir şekilde anlaşılmasıyla ilgili olup, hukuku esas olarak siyasal düzenin temellerini oluşturan kurallar ve ilkeler sistemi olarak görür ${ }^{2}$. Bu çerçevede Anayasa yapmanın asıl anlamı, siyasetin hukuki çerçevesini çizmektir. Ancak, siyasetin hukukileşmesi bir yönüyle de "mahkemelerin veya hakimlerin etkisinin politikacılar ve/veya idareciler aleyhine genişlemesi" sonucunu doğurur. Bu pratik olarak, "önceden devletin diğer kurumlarınca -özellikle de yasama ve yürütme organlarınca- belirlenen (veya, yaygın olarak

\footnotetext{
${ }^{*}$ Hacettepe Ünv. İk. İd. Bil. Fak. Kamu Yönetimi Böl. Öğretim Üyesi

${ }^{1}$ Epstein \& Knight \& Shvetsova 2001: 2.

${ }^{2}$ Loughlin 2000: 193.

${ }^{3}$ Pederzoli \& Guarnieri 1997: 268, dn. 1.
} 
inanıldığ1 üzere, belirlenmesi gereken) kamu siyasetlerininin gittikçe mahkemeler veya hakimler tarafindan belirlenmeye veya bu sürece onların hakim olmaya" başlamaları anlamına gelmektedir" ${ }^{4} \mathrm{Bu}$ olgu günümüzde anayasa mahkemelerinin genel bir eğilimini yansıtmaktadır 5 .

Mahkemeler arasında özellikle anayasa mahkemeleri şüphesiz her yerde siyasi sistemin şekillenmesinde hatırı sayılır bir rol oynarlar. Esasen, anayasa mahkemeleri mahkeme veya yargısal merci olmaktan ibaret değildirler; kararlarının siyasetle ilgili yansımalarıla birlikte onlar aynı zamanda siyasi, en azından yarı-siyasi kurumlar olarak görülebilirler. Kanaatimce, yeni doğmakta olan demokrasilerde anayasa mahkemeleri bu yargının dışında değildirler. Yeni mahkemeler pek muhtemeldir ki demokratik bir siyasal sisteminin tesisindeki payları bakımından siyasi olacaklardır. Bunun için, ben onları doğuş halindeki demokrasilerin kurucuları arasında saymayı tercih ediyorum. Epstein ve diğerlerinin belirttikleri gibi": "Demokratik sistemin temel çerçevesi başlangıçta anayasa yapmak suretiyle belirlenirken, kurumsal yapının adım adım örülmesi zamanla çeşitli siyasi aktörler arasındaki hukuki ve siyasi etkileşimin ürünü olarak gelişir. Prensip olarak, anayasa mahkemeleri öncelikle anayasal ihtilafları anayasanın temel hükümlerini yorumlayarak çözme yetkileri marifetiyle, bu evrimde önemli bir rol oynarlar. Fakat mahkemenin bu otoriteyi etkili olarak kullanma kabiliyeti, önemli ölçüde, onun meşruluğunun bir fonksiyonudur."

Benim bu çalışmadaki hipotezim, anayasa mahkemelerinin demokrasinin pekişmesine birkaç yolla katkıda bulunabilecekleridir. İlk olarak, anayasa mahkemeleri demokrasinin kurulması aşamasında anayasanın üstünlüğünün ve hukuk devletinin tesisine katkıda bulunabilir ve azınlık hakları başta olmak üzere insan haklarını koruyabilirler. Buna anayasa mahkemelerinin "koruyucu" rolü diyebiliriz; nitekim, "negatif yasayıcılar" olarak hareket etmek suretiyle anayasa mahkemeleri yasama ve yürütme organlarını sınırlarlar. Mamafih, eğer bir anayasal demokrasiden veya demokratik hukuk devletinden söz ediyorsak, hukukun üstünlüğünün tesisi ve temel özgürlüklerin devletin tecavüzünden korunması demokrasiyi mümkün kılmanın temel veya zemin şartları olduğundan, başka bir bakış açısından bu pozitif veya kurucu/yapıcı bir rol olarak da görülebilir. Linz ve Stephan'a göre ${ }^{7}$, pekişmiş bir demokrasi için "bütün önemli faktörlerin özellikle demokratik hükümetin ve devlet aygıtının- hukukun üstünlüğüne bağlanması ve ona uyarlanması gerekir. (...) Modern Rechtsstaat demokratikleşmeyi mümkün kılmanın temelidir, çünkü o olmadan

\footnotetext{
${ }^{4}$ Tate 1995: 28, aktaran Epstein ve diğerleri 2001: 35, dn. 1.

${ }^{5}$ Mamafih bu durum bazan da, İtalya'da 1992'den beri olduğu gibi, siyasi kurumların zayıflığından kaynaklanabilir. Çünkü, "yargının gücü (...) diğer politik aktörlerin siyasi taleplere cevap verme kabiliyetiyle ters orantılidır." (Pederzoli\& Guarnieri 1997: 267).

${ }^{6}$ Epstein ve diğerleri, 2001: 33-34.

${ }^{7}$ Linz ve Stephan 2001: 19.
} 
vatandaşlar kendi siyasi haklarını tam bir özgürlük ve bağımsızlıkla kullanamazlar." Ayrıca "devletin bütün kurumları ne kadar hukuk devleti ilkesine göre işlerse, demokrasinin kalitesi o kadar artar ve toplum daha iyi hale gelir."

Anayasa mahkemeleri keza kuvvetler ayrılığını takviye etmek ve kamu otoriteleri arasinda hakemlik yapmak suretiyle de demokrasinin kurulmasina yapıcı katkılarda bulunabilirler. Ĕger bir sistemin devlet organlarının anayasal sınırlarına saygı göstermelerini sağlayacak bir mekanizması yoksa diktatörlük eğilimlerini engelleyecek hiçbir güvence di olmaz. Anayasa mahkemeleri tam da bu hayati amaca hizmet edebilecek olan kurumlardır. Anayasa mahkemelerinin bu işlevini, mahkemelerin genel olarak rejimin meşruluğunu peakiştirmesine katkılarıyla ilişkilendirmek mümkündür ${ }^{8}$. Bu çerçevede, anayasa mahkemeleri anayasal yetki dağ 1 lımına ve demokratik mekanizmanın işleyişine ilişkin otoriteli kararlarıyla, hem vatandaşlarda kurulu sistemin meşruluğu duygusunu hem de siyasal aktörlerin kuralların bağlayıcılığına olan inançlarını pekiştirebilirler.

Şu halde, eğer anayasa mahkemeleri bir şekilde demokratikleşmede önemli iseler, o zaman yeni demokrasilerde, başka kurumlar yanında, anayasa mahkemelerinin kurulmasının ve anayasallık denetiminin pekiştirilmesinin gerekli olduğu söylenebilir. Gerçekten, “... anayasaların etkinliği (Anayasa) Mahkeme(si)nin, devlet içinde siyasi anlaşmazlık çıktığında ve özellikle siyasi aktörlerin üste çıkmak için mücadeleye girişmeleri tehlikesi söz konusu olduğunda, devletin yüksek organlarının işleyişiyle ilgili anayasal hükümleri yorumlama ve teyit etme yoluyla meşruluk kazanma kabiliyetine bağlıdır."

Bununla beraber, anayasa mahkemelerinin politikaya bulaşmada ne kadar ileri gitmeleri gerektiği kesin değildir. Bazıları mahkemelerin en azından demokrasinin kurulması döneminde siyaset oluşturmaya karışmada aktif olmasından yanadırlar. Anayasa mahkemeleri, doğuş halindeki demokrasilerin çoğunda olduğu gibi, hukuk devletinin temelinin sağlam olmadığı bir çevrede çalışmak durumundaysalar, o zaman onların bu eksiği tedavi etmekte acele etmeleri makul bir istek olabilir. Ama öte yandan, müdahaleci yargının ${ }^{10}$ (judicial activism) diğer bazı demokratik aktörlerin yerlerini sağlamlaştırma şansına zarar verme ihtimali de vardır. Stephen Holmes'un ${ }^{11}$ işaret ettiği gibi, anayasa mahkemelerinin müdahaleciliğinin yeni demokrasilerdeki ulusal parlamentoların otorite ve meşruluğunun kurumsallaşmasını baltalama tehlikesi de vardır. Bu meseleyi aşağıda "Son Değerlendirmeler" kısmında ele alacağız.

\footnotetext{
${ }^{8}$ Jacob 1996: 12-13.

${ }^{9}$ Bartole 2002: 430-31

${ }^{10}$ Bu konuda bkz. Erdoğan 2005: 92-95.

${ }^{11}$ Holmes 1993.
} 


\section{MACARISTAN ANAYASA MAHKEMESI: DÖNÜŞÜM SÜRECININ SÜRÜKLEYICI ORTAĞI}

\section{Tarihsel Arkaplan}

Romanya, Doğu Almanya ve Çekoslovakya gibi başka bazı doğuş halindeki demokrasilerden farklı olarak, Macaristan'daki anayasal gelişme devrimci bir kopuştan ziyade resmi hukuk sisteminin sürekliliğini muhafaza eden bir reformlar silsilesinin ürünüdür. " $\mathrm{Bu}$ tür siyasi dönüşümün paradoksal durumu, Macaristan anayasal devletinin kurumsal yapılarının geliștirilip güçlendirilmiş ve temel hak ve özgürlüklerin güvence altına alınmış olmasının, yapılan önemli değişiklikler ve eklerle birlikte Macaristan'ın 1949 tarihli ilk yazılı anayasasının şeklen varlığını sürdürmesinde kendisini göstermektedir." ${ }^{2}$

Ayrıca, Macaristan 1960'lar ve 1970'lerde totaliter bir diktatörlükten, bir dereceye kadar hukukun üstünlügüne ve siyasi meşruluğa yer veren otoriter bir devlete zaten dönüşmüş durumdaydı. Bunun için Macaristan'da demokrasiye geçiş "Kadar dönemi"nin sınırlı reform politikasının bir devamı olarak görülebilir. Bununla beraber, Kadar'ın Mayıs 1988'deki Ulusal Parti Kongresi'nde parti liderliğinden uzaklaştırılmasından sonra süreç hızlandı. Bunu takiben, "1lımlı veya konformist" bir reform hareketi parti liderliğini ele geçirdi. Zamanla, parti içi çatışmaların bir sonucu olarak, 1989'un ilk yarısında demokratik radikal reformcular konformist reformculardan iktidarı devraldılar. Şubat 1989'da Macaristan Sosyalist İşçi Partisi (MSİP) liderlik tekelinden vazgeçerek çok partili bir sistemi kabul etti. 13 Haziran 1989'da "Ulusal Yuvarlak Masa" kuruldu; başlıca üyeleri MSIP, Muhalefet Grubu ve "toplumsal örgütler"di. Parlamento, Yuvarlak Masa görüşmelerinin 18 Eylül'de ulaşılan sonucuyla uyumlu olarak gerekli yasama sürecini başlattı. Ve 23 Ekim 1989'da yürürlüğe giren bir kanun 1949 tarihli olup 1972'de değişikliklere uğratılmış olan eski Anayasanın baştanbaşa gözden geçirilmesini öngördü. Böylece, 1990 Mart ve Nisan aylarında yapılan demokratik seçimlerden sonra oluşan ve eski muhalefet partilerinin ağırlıkta oldukları yeni parlamento yeni anayasa değişikliklerini onaylad ${ }^{13}$.

Anayasa değişiklikleri ve 1989 tarihli Anayasa Mahkemesi Kanunu, başka şeyler yanında, Macaristan'a bir Anayasa Mahkemesi de getirdi. Anayasa Mahkemesi Ocak 1990'da çalışmaya başladı. Tasarlayıcıları onu insan haklarının bekçisi ve kuvvetler ayrılığının kurumsal bir güvencesi olarak düşünmüşlerdi ${ }^{14}$. Akademik camiada, Macaristan Anayasa Mahkemesi'nin sadece eski komünist ülkeler arasında değil fakat dünyada da en aktivist anayasa mahkemesi olduğu konusunda yaygın bir görüş birliği vardır. Esasen, Anayasa Mahkemesi'nin kendisi, "siyasi ihtilafların yarg1

\footnotetext{
${ }^{12}$ Halmai 2002: 189.

${ }^{13}$ Brunner 2000: 67-69; Halmai 2002: 189.

${ }^{14}$ Paczolay 1993: 44.
} 
tarafindan ve hukuki rasyonaliteye göre çözülmesi yolundaki gelişmenin, haklı olarak, siyasi iktidarın hukukileşmesi/yargısallaşması olarak adlandırılabileceği”ni övünçle dilme getirmiştir ${ }^{15}$. Nitekim Macaristan Anayasa Mahkemesi hukuk sistemini yeniden şekillendirmek ve anayasal organlar arasında hakemlik yapmak suretiyle "Macaristan'ın hukuki ve sosyal dönüşümü sürecinin gerçek sürükleyici ortağı" durumundadır ${ }^{16}$. Schwartz'ın ifadesiyle, "Macaristan mahkemesi bütün anayasa mahkemeleri içinde, iktisadi ve sosyal haklar dahil olmak üzere özellikle insan hakları alanında, belki de en atılgan olanıdır"17. Bunun içindir ki, Prochazka Macaristan sistemini bir tür "yargısal demokrasi" olarak nitelemiştir ${ }^{18}$.

Macaristan Anayasa Mahkemesi'nin böylesine kapsamlı bir işlev üstlenmesine yol açan bazı nedenler vardır. Bir tanesi, onun pozitif olarak "uluslararası bir karşılaştırmayla bile son derece geniş bir yargı yetkisi”ne sahip olmasıdır. İkincisi, Macaristan'da hukukun korunması için, idare mahnkemeleri gibi başka önemli kurumların var olmayışıdır ${ }^{19}$. Son olarak, komünizmden anayasal demokrasiye geçiş, Brunner'in anlatımıyla ${ }^{20}$, "hukuk devletinin üstünlüğünü sağlayacak etkin hukuki güvenceler"in sağlanmasını gerektiriyordu.

Denebilir ki, Macaristan'da yargının geçmişi, komünist sistemden tevarüs edilen kurumsal reformun sistemik engellerinin giderilmesi için bölgedeki başka yerlerden daha elverişliydi. Çünkü, yargı özellikle son yirmi yılda yasama ve yürütmeden nispeten bağımsızdı ve hakimler komünist ve Nazi dönemlerinde bile belli dereceye kadar bir kişisel dürüstlüğü muhafaza edebilmişlerdi ${ }^{21}$. Muhtemelen bunun içindir ki Macarlar Anayasa Mahkemesi'nin parlamento veya hükümetten ziyade topluma hizmet ettiğini düşünmektedirler ${ }^{22}$. Şüphesiz bu halk desteği Mahkeme'nin kendi işini oldukça atak biçimde yapmasını kolaylaştırmaktadır.

\section{Mahkemenin Yapısı ve İșleyiși}

Anayasa Mahkemesi Kanunu'na göre, Mahkeme bir başkan ve on üyeden oluşmaktadır. Üyelerin tamamı Parlamento tarafından üçte-iki oy çokluğuyla seçilmektedir. Hakimlerin görev süresi 9 yıldır ve bir defaya mahsus olmak üzere tekrar seçilmek mümkündür. Üyeler kendi aralarından

\footnotetext{
${ }^{15}$ The Constitutional Court of Hungary, "National Report", aktaran Prochazka 2002: 134.

${ }^{16}$ Prochazka 2002: 78; Paczolay 1993: 44-45; Sadurski 2002, "Introduction”: 3; Sadurski

2002, "The Legitimacy...": 164; Brunner 2002: 93.

${ }^{17}$ Schwartz 1999: 204.

${ }^{18}$ Prochazka 2002: 78,

${ }^{19}$ Halmai 2002: 192.

${ }^{20}$ Brunner 2002: 93.

${ }^{21}$ Prochazka 2002: 35.

${ }^{22}$ Schwartz 20002: 107.
} 
üç yıllık bir dönem için Başkanı ve Başkan Yardımcısını seçerler, bunların yeniden seçilmelerinde bir sınırlama yoktur. Mahkeme üyesi seçilebilmek için 45 yaşını doldurmuş ve hukuk eğitimini tamamlamış olmak gerekir. Ayrıca, üniversite profesörleri veya "Siyasi ve Hukuki Bilimler"de doktora derecesine sahip olanlar ile bir dalda uzmanlaşmış olan 20 yıllık mesleki tecrübeye sahip olan uygulamacilar da Mahkemeye üye olabilirler. Ancak, parti üyeliği veya siyasi faaliyet anayasa hakimliğiyle bağdaşmaz. Anayasa Mahkemesi üyeliği, başka nedenler yanında, istifa, görevini yerine getirememe veya meslekten çıkarılma durumunda sona erer. Son iki durumda üyeliğin sona ermesine yine Anayasa Mahkemesi'nin kendisi karar verir. Bir anayasa hakimi bakanların sahip oldukları ayrıcalıklara ve bir milletvekilinin ödenek ve bağışıklığına sahiptir ${ }^{23}$.

Mahkeme bütün üyelerin katıldığı genel kurul halinde veya üç kişilik kurullar şeklinde karar verebilir. Genel kurul oturumlarında toplantı yeter sayısı Başkan veya Başkan Yardımcısı dahil olmak üzere sekizdir. Üç hakimli kurullar, anayasa şikayeti dahil olmak üzere, daha az önemli uyuşmazlıklara bakarlar; üyelerin üçünün de oturumlarda hazır bulunması gerekir. Her durumda kararlar çoğunlukla alınır ${ }^{24}$. Mahkemenin Genel Sekreterlik, Başkanın Sekreteryası ve Bütçe Dairesi olmak üzere üç idari birimi vardir ${ }^{25}$.

\section{Mahkemenin Yetkileri}

Mahkemenin yetkisinin esasını, yürütmenin tüzükleri ve kararnameleri de dahil olmak üzere, hukuk normlarının soyut denetimi oluşturmaktadır.

\section{a) Önleyici Norm Denetimi}

Anayasa Mahkemesi normları soyut olarak incelemesi (a) Parlamentonun kanun tasarılarını (Parlamentonun talebi üzerine), (b) Parlamentonun İçtüzük kurallarını kabul edilmelerinden önce, (c) kanunları ilan edilmeden önce, uluslararası antlaşmaları Parlamento tarafından onaylanmadan önce incelemeyi kapsar. (Ancak, Anayasa Mahkemesi, bunun yasama sürecine müdahale anlamına geleceğini söyleyerek, kanun tasarılarını inceleme yetkisinden kendi isteğiyle 1991 yılında vaz geçmiş ve bu yetki 1998 yılında kanundan çıkarılmıştır ${ }^{26}$.

\section{b) Düzeltici Norm Denetimi}

Yürürlüğe girmiş olan hukuki normların yasalaşma sonrası veya geriye dönük olarak denetlenmesi Mahkeme'nin asıl işini oluşturmaktadır. Düzeltici norm denetimi yoluna herkes başvurabilir (actio popularis).

\footnotetext{
${ }^{23}$ Brunner 2000: 71-73.

${ }^{24}$ Brunner 2000: 71-73.

${ }^{25}$ Brunner 2000: 75-76.

${ }^{26}$ Halmai 2002: 193; Brunner 2000: 79.
} 
Düzeltici denetim somut norm denetimi biçiminde de yapılabilir. Anayasa Mahkemesi Kanunu'na göre, "bir hakim (davada) uygulanacak bir hukuk normunun veya idari hükmün anayasaya aykırı olduğu kanaatine varırsa, davayı durdurması ve sorun hakkında Anayasa Mahkemesi'nden bir karar talep etmesi gerekir."27 Eğer Mahkeme bir hukuk normunun veya idari hükmün anayasaya aykırı olduğunu tespit eder ve onu iptal ederse, bu norm kararın Resmi Gazete'de yayımlanmasından hemen sonra uygulanabilirliğini yitirir.

\section{c) Yasama Görevini Anayasaya Aykırı Olarak İhmal}

$\mathrm{Bu}$ usul anayasaya aykırı yasama görevi ihmallerini tesbit etmek için getirilmiştir. Buna göre, Anayasa Mahkemesi, bir kamu otoritesinin hukukun gerektirdiği bir kural-koyma görevini yerine getirip getirmediğini tespit etme yetkisi vardır. Parlamentonun ihmal şeklinde kendisini gösteren anayasaya aykırılığını belirleme yetkisi, Mahkeme'ye, anayasaya aykırı ihmali veya yasamadan kaçınmayı telafi etmek üzere ilgili kurume harekete geçmesini emretme yetkisi verir ${ }^{28}$. Eğer Mahkeme böyle bir ihmalin varlığını tespit ederse, ilgili kamu otoritesine gerekli normu yapmak üzere muayyen bir süre tanır. Böyle bir usule Mahkeme tarafından re'sen başvurulabileceği gibi, herhangi bir kişi de böyle bir tespiti yapması için Mahkemeye başvurabilir ${ }^{29}$.

\section{d) Antlaşmalara Uygunluğun Denetimi}

Anayasa Mahkemesi, başvuru üzerine veya re'sen bir hukuk normunun uluslararası bir antlaşmayu uygunluğunu inceleyebilir. Eğer antlaşmayla çelișen ulusal bir hukuk normu onunla aynı düzeyde veya daha alt düzeydeki bir norm ise, Mahkeme'niun bu normu iptal etmesi gerekir. Eğer söz konusu iç hukuk normu antlaşmadan daha üst düzey bir norm ise, o zaman da Mahkeme ya antlaşmanın uygulanmasından sorumlu olan organın belli bir süre içinde değişiklik yapmasını ya da sorumlu kural-koyucu organın yine belli bir süre içinde ulusal hukuk normunu antlaşmaya uygun hale getirmesini ister ${ }^{30}$.

\section{e) Anayasa Şikayeti}

Kendisinin bir temel hakkının anayasaya aykırı bir normun uygulanması suretiyle ihlal edildiği kanaatinde olan herkes şikayet yoluyla Anayasa Mahkemesi'ne başvurabilir. $\mathrm{Bu}$ hakkı kullanmak isteyen şikayetçinin bütün kanun yollarını tükettikten sonra kesin hükmü takip eden 60 gün içinde başvurusunu yapması gerekir. Şikayet yolu aslında düzeltici norm denetiminin bir çeşididir; bunda sahici anlamda bir anayasal şikayetten ziyade bir bireysel hakkın ihlal edilmiş olması söz konusudur ${ }^{31}$.

${ }^{27}$ Brunner 2000: 82.

${ }^{28}$ Schwartz 2000: 79-80.

${ }^{29}$ Brunner 2000: 85-86; Schwartz 2000: 79-80.

${ }^{30}$ Brunner 2000: 87.

${ }^{31}$ Brunner 2000: 84. 


\section{f) Anayasanın Yorumlanması}

Macaristan Anayasa Mahkemesi, talep üzerine, Anayasanın bir hükmü hakkında soyut olarak bağlayıcı bir yorum kararı verebilir ${ }^{32}$.

\section{Mahkemenin İctihadının Özellikleri}

\section{a) Kurucu Yorum}

Buna yaratıcı yorum da denebilir. Her iki terimle de genel olarak anlatılmak istenen, anayasa mahkemelerinin, kimi anahtar kavramları kullanmak veya inşa etmek suretiyle, hukuk sistemindeki boşlukları doldurma veya eksikleri telafi etme konusundaki isteklilikleridir. Macaristan'da kurucu anayasal yorumu kolaylaştıran ana etken metinlerin geçici karakteridir. Bu, Macaristan Anayasa Mahkemesi'nin "mevcut anayasal metinlerin ötesine geçerek, sırf kanunun lafzından ziyade, büyük ölçüde hukuk teorisinden ve siyaset felsefesinden kaynaklanan ayrıntıl1/iyi işlenmiş bir yargısal içtihat geliştirmesine yardım etmiştir." 33

Anayasa Mahkemesi'nin bunu yaparken geliştirdiği ve yararlandığı kavramsal aygitlardan biri "görünmez Anayasa" veya bir "dogma sistemi"dir. Bu kavramlarla, Amerikan Yüksek Mahkemesi dahil dünyanın önde gelen ulusal ve uluslararası mahkemelerinin kullandığ 1 çağdaş anayasa doktrininden çıkarılan ilkeler ve metodoloji" anlatılmak istenmektedir ${ }^{34}$. Mahkeme'nin kendisi 1990 yılında şöyle diyordu: “Anayasa Mahkemesi Anayasa'nın ötesinde güvenilir bir anayasallık standard1 -bir 'görünmez Anayasa'- oluşturmak üzere, Anayasa'nın teorik temellerini ve onun yer verdiği hakları açıklama ve kararlarıyla tutarlı bir sistem oluşturma çabasına devam etmelidir; böylece 'görünmez anayasa' muhtemelen yerleştirilmek durumunda olan yeni Anayasayla veya gelecek Anayasalarla çatışmayacaktır. Anayasallık kavramının çerçevesi içinde kaldığı müddetçe bu süreçte Anayasa Mahnkemesi özgürdür." 35

Mahkemenin kullandığı başka bir anahtar kavram, "kaynak hak/hakların anası" (mother right) olarak genel kişilik hakkıdır. Mahkeme 1990 tarihli bir kararında bu genel hakkı Anayasa'nın tanıdığ 1 "insan onuru doğal hakkı"na (m. 54/1) dayandırmıştır. Sonraki yıllarda Mahkeme insan onuru hakkından "öz-kimlik ve kendisini-belirleme hakkı" yanında, anayasa tarafından açı olarak tanınmış olmayan geyler ve lezbiyenler arasında hukuken tanınan evlenme hakkı gibi yeni haklar türetmeye devam etmiştir."36

${ }^{32}$ Halmai 2002: 194-95,

${ }^{33}$ Prochazka 2002: 275.

${ }^{34}$ Schwartz 2002: 82.

${ }^{35}$ Decision of the HCC No. 23/1990 (X.16); aktaran Prochazka 2002: 58.

${ }^{36}$ Halmai 2002: 199-200; Bartole 2002: 44. Daha ayrıntılı bir liste için bkz. Prochazka 2002: 


\section{b) İnsan Hakları ve Hukukun Üstünlüğü}

Demokratik Macaristan'ın ilk seçilen parlamentosu 21 Aralık 1944 ile 2 Mayıs 1990 arasında işlenmiş suçların koğuşturulmasını öngören bir kanunu kabul etti. Cumhurbaşkanının Kasım 1992'deki başvurusu üzerine Anayasa Makemesi bu geçmișe dönük adalet girișimini, anayasal bir devletin güvence altına alması gereken temel ilkelerden biri olan hukuki güvenliği ihlal ettiği gerekçesiyle, anayasaya aykırı bularak iptal etmişir. Mahkemeye gore, Kanun, kanuna dayanmayan suç ve suça dayanmayan ceza olamayacağ 1 şeklindeki iki temel ceza hukuku ilkesini ihlal ediyordu. ${ }^{37}$

\section{c) "Temizlik"}

Parlamento 1994 başlarında kilit kamusal mevkilerde olan kişilerin geçmişlerinin hakimlerden oluşan üç kişilik kurullar tarafindan gizli polis dosyalarına girilerek araştırılmasını gerektiren bir kanunu kabul etti. $\mathrm{Bu}$ kişiler, eski rejim döneminde, insan hakları ihlali niteliğinde olan gizli polis için veya infaz kurumları için çalışmış olmak gibi faaliyetler yapıp yapmadıklarının tespit edilmesi için araştırmaya tabi tutulacaklardı. "Eğer yapmışlarsa, o zaman kurul kişiyi kanıtlardan haberdar edecek ve ona görevinden ayrılması için bir şans verecek, ancak kişi görevde kalmayı seçerse kurul bu bilgiyi açıklayacaktı. Eğer kişi dosyalarda bulunan bilgiye itiraz ederse, o zaman açıklamadan önce kişi kanıtları gizli olarak inceleyecek ve somut olayda hüküm verecek olan bir mahkemeye başvurabilecekti. Eğer kişi kendisi aleyhindeki hükmü kabul eder ve istifayı seçerse, o takdirde bu bilgi yine gizli kalacaktı ${ }^{38}$.

Anayasa Mahkemesi bütün vatandaşların özel hayatın gizliliği temel hakkını ve halkın kamu yararına olan bilgiye ulaşma anayasal hakkını ihlal etiği gerekçesiyle bu kanunu kısmen anayasaya aykırı buldu. Mahkeme ayrıca, bütün vatandaşların mahremiyet hakkını olduğu kadar bilgi edinme yoluyla kendisini belirleme hakkını da güvence altına alacak düzenlemeyi yapmadığı gerekçesiyle, eski dosyalar sorununun yasama organı tarafindan ele alınma biçiminin anayasal olarak eksik olduğuna karar verdi. Başka bir ifadeyle, Anayasa Mahkemesi Parlamentoyu bu meseledeki teşrii ihmalini telafi etmeye zorladi ${ }^{39}$.

\section{d) İktidar Haritası}

Cumhurbaşkanı ile başbakan arasında çıkan bir anlaşmazlık üstüne Anayasa Mahkemesi 23 Eylül 1991'de parlamenter bir hükümet sisteminde başbakan tarafından üst kademe görevler için önerilen adayları cumhurbaşkanının veto etme yetkisinin bulunmadığını belirten bir anayasal

227-28.

${ }^{37}$ Decision 11/1992, Solyom \& Brunner 2000: 214-28.

${ }^{38}$ Halmai 2002: 197.

${ }^{39}$ Halmai 2002: 197; Schwartz 2000: 102-103 
yorum kararı verdi ${ }^{40}$. Başka bir anlatımla, ancak "atamayı düzenleyen bir hukuk normunun var olmaması durumunda veya atanması önerilen kişinin soruş̧turulması sonucunda atanacak kişinin ulusun demokratik sürecini ciddi oalarak zedeleyeceği kanaatine götürecek maddi bir bulguya ulaşması durumunda" ${ }^{41}$ Cumhurbaşkanı bir atamayı rededebilirdi.

\section{POLONYA ANAYASA MAHKEMESİ: PARLAMENTO'NUN YARDIMCILIĞINDAN MÜDAHALECİLİĞE}

\section{Tarihi Arkaplan}

Polanya Avrupa'da ilk yazılı anayasaya sahip olan ülke idi, ancak Polonya 1795 yılında bağımsızlığını kaybettiği için, 3 Mayıs 1791 tarihli bu anayasa hiç yürürlüğe girmemişti. Polonya 1918'de yeniden bağımsızlığını kazandı ve 1921 Anayasası Polonya devletini yeniden kurdu. Fransızların "yasamanın üstünlüğ̈̈̈" anlayışından büyük ölçüde etkilenmiş olan bu anayasa "hukuki olarak ilan edilmiş olan kanunlar"ın yargı tarafindan denetlenmesini yasakliyordu ${ }^{42}$.

Polonya'da anayasa yargisı ilk defa 1952 tarihli anayasada Mart 1982'de yapılan bir değişiklikle kuruldu. Üç yıl sonra, 1985'te, mahkemenin kuruluş kanunu çıkarıldı. Bu Sovyet İmparatorluğundaki ilk anayasa mahkemesiydi. Bu Anayasa Mahkemesi 1986-1997 arasında faaliyet gösterdi. Bugün görev yapmakta olan mahkeme ise Nisan 1997'de kabul edilen Anayasa'yla kurulmuş̧tur. Yeni Anayasa Mahkemesi Ekim 1997 itibariyle çalışmaya başladı ${ }^{43}$.

\section{Anayasa Mahkemesinin Yapısı ve Yetkileri}

Polonya Anayasa Mahkemesi parlamento (Sejm) tarafindan atanan on iki hakimden oluşmaktadır. Sekiz yıllık dönemler için atanan üyeler tekrar seçilemezler. Üyelerin yarısı dört yılda bir yenilenir. Anayasa Mahkemesi üyeleri genellikle seçkin hukukçulardır.

Mahkeme anayasallık ve hukukilik sorunlarını re'sen inceleyebilir. 1997 Anayasası anayasal haklarının ihlal edildiğini düşünen herkese, ilgili kanunun anayasaya uygunluğu hakkında karar vermesi talebiyle Mahkemeye başvurma hakkı tanımaktadır ${ }^{44}$.

\footnotetext{
${ }^{40}$ Schwartz 2002: 198.

${ }^{41}$ Halmai 2002: 198.

${ }^{42}$ Schwartz 2000: 49-50.

${ }^{43}$ Prochazka 2002: 37-38.

${ }^{44}$ Schwartz 2000: 53.
} 
1997 Anayasası, Mahkeme'nin, daha önce var olan, yüksek kamu görevlileri tarafından istenmesi halinde alelade kanunların bağlayıcı yorumunu yapma yetkisini olduğu gibi, Anayasa Mahkemesi’nin kanunların anayasaya aykırılığını tespit eden kararlarını parlamentonun geçersiz kılma yetkisini de kaldırmıştır ${ }^{45}$.

\section{Mahkemenin İctihadı}

\section{a) Müdahalecilik}

Çalıșmaya başlamasından hemen sonra Mahkeme 1987 yılında yürütmenin bireysel haklar konusunda yetki kullanmasına karşı çı1kmış ${ }^{46}$, parlamento karşısında ise ona yardımcı olmak şeklinde bir rolü benimsemiş ve genel olarak yasama üstünlügünnden yana tavır alarak yürütmenin aşırılıklarına karşı durmaya devam etmiştir ${ }^{47}$. 1989'dan önce, Schwartz'ın ifadesiyle ${ }^{48}$, "Mahkeme çabasını kanun-altı işlemleri kanuni ve anayasal sınırlar içinde tutmaya yoğunlaştırmak suretiyle rejimin beklentilerini yerine getirmiş ve yasama üstünlüğüne aslında itiraz etmemiştir." Başka bir anlatımla, bu dönemde mahkeme dönüşümle ilgili politikaları denetlerken hatırı sayılır derecede kendisini sınırlamıştır ${ }^{49}$.

Bununla beraber, eski rejimin çöküşü durumu değiştirmiş ve Polonya “anayasa yargısının ciddi olarak özgürleşmesi”yle sonuçlanmıştır. Nitekim, Anayasa Mahkemesi 1989'dan sonraki dönemde "yasamanın üstünlügü̈" anlayışını terkederek kanunların denetlenmesinde daha aktif davranmaya başlamıştır. Radoslav Prochazka, Polonya Anayasa Mahkemesi'nin bu dönemde "hızla ülkenin anayasal politikasında anayasayı yapanların öngördüklerinin ötesine geçen bir konuma yükseldiği'"ni ${ }^{50}$ belirtmektedir. Bunun en belirgin bir işareti Mahkeme'nin Rechtsstaat'la ve eşit hukuki korumayla ilgili anayasal hükümleri kullanma tarzıdır. Bu geçiș, pek muhtemeldir ki, Mahkeme'nin üye yapısının ve siyasi çevresinin değişmesinin olduğu kadar, 1989 anayasa değişikliklerinin de bir sonucudur $^{51}$.

Sebepleri ne olursa olsun, 1989'dan buyana Polonya Anayasa Mahkemesi genellikle kanunları kısmen veya tamamen iptal etmiştir. Nitekim, 1 Ocak 1990'dan 30 Haziran 1994'e kadar Mahkeme incelediği 55 kanunun 40'ını anayasaya aykırı bulmuştur ki, Amerikan Yüksek

${ }^{45}$ Schwartz 2000: 73; Garlicki 2002: 267.

${ }^{46}$ Schwartz 2000: 58.

${ }^{47}$ Prochazka 2002: 88 .

${ }^{48}$ Schwartz 2000: 55.

${ }^{49}$ Prochazka 2002: 84

${ }^{50}$ Prochazka 2002: 88

${ }^{51}$ Schwartz 2000: 55. 
Mahkemesi'nin uygulmasıyla karşılaştırıldığında, bu çok yüksek bir orandir ${ }^{52}$.

Anayasa Mahkemesi ayrıca kendisine böyle bir yetki vermeyen 1985 tarihli kanuna ve 1989 Anayasasına aykırı olarak, antlaşmaların anayasaya uygunluğunu denetlemeyi kendi yetki alanına dahil etmek suretiyle yetkisini genişletmeye çalışmıştır. Bununla beraber, eski (ve yeni) anayasaya gore, belirli özel durumlar dışında, antlaşmaların bir kanunla onaylanması gerekmektedir. 1994'te ombudsmanın gönderdiği bir soruya cevaben Mahkeme bu gibi kanunlar üzerinde denetim yetkisine sahip olduğunu teyit ederek antlaşmanın kendisinin anayasaya uygunluğunu da inceleme hakkı olduğunu ileri sürmüştür ${ }^{53}$.

Başka bir seferinde Anayasa Mahkemesi kendi yetkisini parlamentonun aleyhine genişletmiştir. Cumhurbaşkanının başvurusu üzerine Mahkeme Eylül 1995 'te, kendisinin parlamentodan geçen bir tasarıyı anayasaya aykırı bulması halinde parlamentonun bu kararı geçersiz kılamayacağına karar verdi. Ancak daha önce Cumhurbaşkanı tarafından ilan edilmiş olan kanunları iptal eden kararların parlamentoya sunulması gerekmektedir ${ }^{54}$.

\section{b) Hukuk Devleti (Rechtsstaat) Hükmü}

Polonya Anayasa Mahkemesi özellikle ilk döneminde hukuk sisteminin birçok boşluğunu doldurmuş ve Anayasanın eski metnini rejim değişikliğinin gereklerine uyarlamak suretiyle Polonya'da hukukun üstünlğünün tesisine hizmet etmiştir. Mahkeme ayrıca Batı anayasacılığının anahtar kavram ve ilkelerinin Polonya'ya taşınmasına katkıda bulunmuştur. $\mathrm{Bu}$ yolla hem parlamento hem de hükümet modern hukuk devletine özgü kularlara alışkanlık kazanmıştır ${ }^{55}$. Mahkeme'nin yorumu sayesinde, Anayasa'nın metninde yer almayan kanunların geçmişe yürümezliği, insan onuruna sayg1, hayat hakkı, hakların yasal düzenlenmesinde ölçülülük, özel hayat hakk1, vatandaşların hükümete güvenmesi, kazanılmış haklara saygı, kanunun açıklık ve kesinliği gibi çok sayıda hak, ilke veya değeri içine alacak şekilde anayasal Rechtsstaat hükmünün kapsamı genişlemiştir. Mahkeme yerinde bir tutumla, bu ilke ve easasları Polonya'nın standart bir anayasal demokrasiye geçebilmesi bakımından kaçınılmaz görmüştür ${ }^{56}$.

\section{c) Anti-Komünist Temizlik Tedbirleri}

Polonya Anayasa Mahkemesi Komünist karşıtı tedbirleri genel olarak onaylamış olmakla beraber, hukuki kesinlik, kanunların açık-seçikliği ve yargının bağımsızlığı ilkeleri üstünde 1srarlı olmuştur. Mahkeme iki ayrı

${ }^{52}$ Schwartz 2000: 55-56.

${ }^{53}$ Schwartz 2000: 63.

${ }^{54}$ Schwartz 2000: 63.

${ }^{55}$ Garlicki 2002: 281; Bartole 2002: 426.

${ }^{56}$ Prochazka: 209-210. 
kararında "üst kademe görevlere seçilecek veya atanacak olanların Haziran 1944-Mayıs 1990 arasında gizli polisle 'bilinçli olarak işbirliği yapıp yapmadıkları'nı açıklamalarını gerektiren bir temizlik kanununu" anayasaya uygun bulmuştur. Kanuna göre, böyle yaptıklarını kabul eden kişiler, bunu alenen itiraf etmedikçe artık hiç bir resmi görev alamazlardı; ama eğer bunu gerçeğe aykırı olarak inkar ederlerse, bunun ortaya çıkması halinde on yıl süreyle kamu görevinden yasaklanacaklardı. Öte yandan, 1998'de Mahkeme hakimlerle ilgili benzer bir kanunu da Ulusal Hakimler Kurulu'na danışılmadığı gerekçesiyle anayasaya aykırı bulmuştur ${ }^{57}$.

\section{d) Yetki Haritası}

Cumhurbaşkanı ile hükümet arasında Radyo ve Televizyon Kurulu'nun başkanının görevden alınması konusunda 1994 yılında bir anlaşmazlık çıktı. Konuyla ilgili 1992 tarihli kanun cumhurbaşkanına Kurul başkanını aday gösterme yetkisi tanımakla beraber, onun görevden alınması konusunda herhangi bir hüküm içermiyordu. Ombudsmanın bu kanunun yorumu hakkındaki yorum talebi üstüne, Mahkeme hukuka bağlı devlet ilkesi gereğince bir devlet organının kendisine açıkça verilmiş olmayan bir yetkiyi kullanamayacağını açıklamıştır ${ }^{58}$.

\section{IV. ÇEK ANAYASA MAHKEMESİ: META-ANAYASACILIĞIN MÜELLİFI}

\section{Cekoslovakya Gecmiși}

Çekoslovakya'nın Fransız ve Amerikan anayasacılığından etkilenmiş olan ilk Anayasası 1920 yılında kabul edildi. Anayasa Parlamentonun işlemlerinin anayasaya uygunluğunu denetleyecek bir Anayasa Mahkemesi kurdu. Bu Mahkeme 1921'den 1941'e kadar faaliyet göstermiştir. Warşova Paktı güçlerinin 1968 Ağustos'undaki işgalinden sonra, Çekoslovakya Federasyonu hakkındaki 1968 tarihli Anayasal Kanun Çekoslovak anayasal sistemini yeniden şekillendirdi, bu arada federal ve ulusal yasama işlemlerinin anayasaya uygunluğunun denetimini tesis etti. Fakat bu konuda yasal düzenleme yapılmadığ 1 için, yargısal denetim uygulamaya geçmedi ${ }^{59}$.

Komünizmin çöküşünü takiben, 1991 yılında "Çek ve Slovak Federal Cumhuriyeti Anayasa Mahkemesi" kuruldu ve aynı yıl Mahkemenin kuruluş kanunu parlamentodan geçti. Mahkeme, altısı Çek altısı Slovak Cumhuriyeti'nden olmak üzere, on iki hakimden oluşuyordu. Üyeler ulusal

\footnotetext{
${ }^{57}$ Schwartz 2000: 67-69

${ }^{58}$ Schwartz 2000: 67-69.

${ }^{59}$ Priban 2002: 373-75.
} 
parlamentolar tarafindan öneriliyor ve Federal Meclis tarafından onaylanıp Cumhurbaşkanı tarafından yedi yıllık bir süre için atanıyordu. Mahkeme Parlamento işlemlerini ve alt derece mahkemelerinin kararlarını anayasal kanunlara ve insan haklarıla ilgili uluslararası antlaşmalara uygunluk açısından denetleme yetkilerine sahipti ${ }^{60}$.

Ancak Federal Anayasa Mahkemesi Şubat-Aralık 1992 arasında, yani sadece on ay çalışt1.

\section{Cek Anayasa Mahkemesi'nin Doğușu ve Yetkileri}

Çekoslovak Federasyonu'nun dağılmasından ("kadife boşanma”) sonra, 1992 Aralık'ında Çek Anayasası kabul edildi. Anayasada Anayasa Mahkemesi'ne başlı başına bir bölüm ayrılmıştı 1993 sonlarında faaliyet geçen Mahkeme, on yıllık bir süre için Cumhurbaşkanı tarafından atanan ve bilahare Senato tarafindan onaylanan onbeş hakimden oluşuyordu ${ }^{61}$.

Çek Anayasa Mahkemesi'nin parlamentonun Anayasaya veya insan haklarıyla ilgili uluslararası antlaşmalara aykırı işlemlerini soyut norm denetimi yoluyla geçersiz ilan etme yetkisi vardır. Anayasa Mahkemesi "diğer bütün hukuki işlemleri denetleme ve onları kanunlara uygun olmamaları halinde iptal etme yetkisi sayesinde hukuka uygunluğun da bekçisidir." Çek Mahkemesi ayrıca yerel yönetim organlarının hükümet müdahalesine karşı yaptığı şikayet başvurularını dinleme ve bölge idareleriyle yerel makamlar arasındaki yetki uyuşmazlıklarını çözme yetkisine sahiptir. Mahkeme'nin son olarak bireylerin anayasal haklarının ihlal edildiği iddiasıyla yapacakları şikayetleri de inceleme yetkisi vardır. Anayasa Mahkemesi'nin kararları bütün makamları ve kişileri bağlar ${ }^{62}$.

İlginç bir nokta, Çek Anayasa Mahkemesi'nin halihazırdaki demokratik meşruluğunun, Parlamento'nun her iki kanadının da kamusal desteğinden daha güçlü olmasıdır. Bu durum Mahkeme'nin ülkenin demokratik siyasetinde önemli bir aktör olarak ortaya çıkarmasını mümkün kılmıştır. Öte yandan, bu kamusal desteği ve demokratik meşruluğu sayesinde, Anayasa Mahkemesi hukuk sistemini ve hukuki gelenekleri anayasaldemokratik hukuk devletinin gereklerine uyacak şekilde temelden değiştirebilmiştir ${ }^{63}$.

\footnotetext{
${ }^{60}$ Priban 2002: 376.

${ }^{61}$ Priban: 376-78.

62 Priban 2002: 377; Prochazka 2002: 140.

${ }^{63}$ Priban 2002: 394.
} 


\section{Mahkeme'nin İctihadı}

Jiri Priban'a göre, Çek Anayasa Mahkemesi her zaman yargısal bir organ olmaktan çok yasama gücünün bir ortağı olmaya çalışmıştır. Bu eğilim kendisini Parlamento'nun yasama yetkisi ile Mahkeme'nin yetkisi arasındaki ilişkilerde göstermektedir. Anayasa Mahkemesi demokratik meşruluk ve demokratik hukuk devleti için anayasal destek sağlarken, o aynı zamanda yasama organına ve onunu muhtemel siyasi üstünlügüne de karşı çıkmaktadır ${ }^{64}$.

Çek Anayasa Mahkemesi geçiş dönemindeki genel tutumu itibariyle bir anayasal hakem ve bir sosyal dönüştürücü olarak hareket etmiştir. Yeni rejimin ideolojisini benimsediği için de Parlamento'nun dönüşüme ilişkin temel tercihlerine de saygı göstermiştir. Bu bağlamda, birçok eski rejim muhalifinin üye olarak atanmasıyla yeni rejimin ideolojisine bağlılı̆g 1 pekişen Mahkemenin üyelerinin çoğu geçmişe yönelik saldırıları desteklemeyi doğal saymıştır ${ }^{65}$.

\section{a) Komünist Rejimin Meşruluğu}

"Komünist Rejimin Hukuksuzluğu ve Ona Karşı Direniş Hakkında Kanun"un anayasaya uygunluğuyla ilgili 1993 tarihli ilk davada Mahkeme eski rejimin meşruluğu problemini ele almıştır. Bu davada Mahkeme anayasanın değerler bakımından tarafsız olmadığına, aksine demkratik bir toplumun temel değerlerini yansitan muayyen fikirleri içerdiğine karar vermiştir. Meşruluk problemini dar anlamda kavramayı reddederek, sırf hukuk sistemindeki devamlılıktan dolayı komünist rejimin meşru olamayacağını belirtmiştir. Anayasa Mahkemesi yeni liberal-demokratik anayasa'nın meşruluğun dar anlamda "yasallık" şeklinde anlaşılmasına izin vermediğine hükmetmiştir. Mahkemeye göre, meşruluğun demokratik siyasi toplumun değerleri çerçevesinde anlaşılması gerekir, yani siyasi rejimin meşruluğu demokratik siyasi ilkelerden kaynaklanır. Başka bir ifadeyle, hukuka bağlı bir devlette meşruluk onun demokratik özelliğine dayanır ${ }^{66}$.

Anayasa Mahkemesi böylece tarihsel adalete hizmet edeceği düşünülen söz konusu kanunu tümüyle onaylamıştır. Mahkeme için, ceza adaletiyle ilgili usuli gerekler anayasal hakların kapsamı dışında kalıyordu. Ona gore, Anayasanın Haklar Bölümü hangi suçların koğuşturulabileceğini açıkça göstermiş olmakla beraber, bunların ne kadar süreyle koğuşturulabilecekleri konusunda herhangi bir hükme yer vermiyordu. Mahkeme ayrıca, eski rejim bu kanunun kapsadığı suçları cezalandırmaktan bilinçli olarak kaçındığı için, geçmişe dönük adaleti öngören bu kanunun yenilik doğurucu nitelikte olmayıp açıklayıcı bir norm olduğunu da ileri sürmüştür ${ }^{67}$.

\footnotetext{
${ }^{64}$ Priban 2002: 378-82.

${ }^{65}$ Prochazka 2002: 140, 145.

${ }^{66}$ Priban 2002: 383; Prochazka 2002: 146, 235-36.

${ }^{67}$ Prochazka 2002: 146.
} 


\section{b) Yasama Organının Ortağı}

Yetkileri bamıkından Çek Anayasa Mahkemesi yasama gücünün anayasal bekçisi olarak düzenlenmiştir. Nitekim Mahkeme yasama organının frenleyici ortağı gibi hareket etmektedir. $\mathrm{Bu}$, tahmin edilebileceği gibi, Parlamento'yla Mahkeme arasında birçok ihtilafın ortaya çıkmasına yol açmaktadır. Bunun bir nedeni, Mahkeme'nin biçimci bir yasallık anlayışını ve parlamentonun üstünlüğünü reddetmesidir. Anayasa Mahkemesi dar hukuki pozitizvim yaklaşımını reddetmiş ve liberal-demokratik siyasi değerlerle uyumlu olacak daha geniş bir hukuk anlayışı arayışı içinde olmuştur $^{68}$.

Mahkeme bu bağlamda şöyle demiştir:

"Modern demokratik yazılı anayasa kurucu iktidarı temsil eden halkın kendisini siyasi bir varlık olarak kurmasına aracılık eden ve bireyin bütünle ve devlet kurumları sistemiyle ilişkisini gösteren bir sosyal sözleşmedir. Genel olarak kabul edilen temel değerleri kurumsallaştıran ve meşru iktidar kararlarının oluşum mekanizmasını ve sürecini şekillendiren bir belge, demokratik kurumların anlamı, amacı ve işleyiş tarzına ilişkin anlayışların olduğu kadar, kamusal olarak kabul edilen değerlerin ve adalet anlayışlarının da dişında var olamaz. Başka bir ifadeyle, anayasanın değerler ve kurumlara ilişkin asgari bir konsensüs olmadan işlemesi mümkün değildir. Bundan hukuk alanı için çıkan sonuç, bir pozitif hukuk sisteminde bile, temel hukuk ilkelerinin ve teamüllerin genel olarak hukukun olduğu kadar anayasa hukukunun da kaynakları arasında yer alması gerekttiğidir.,"69

Diğer taraftan, yasama organının ortağı olarak Anayasa Mahkemesi zaman zaman da, "anayasaya uygun yorum"da örneklendiği gibi, kendisini kısıtlamıştır. "Gerekli olmadıkça iptal etmeme" kuralı olarak da adlandırılan bu yöntem Anayasa Mahkemesi'nin geliştirdiği bir yargısal tekniktir. Buna göre, "bir kuralı Anayasa'nın gerekleriyle uyumlu olarak uygulanmasına imkan verecek şekilde yorumlamak mümkünse, böyle bir yorum kuralın iptaline tercih edilmelidir." ${ }^{, 70}$

Anayasa Mahkemesi bu demokratik meşruluk anlayışını egemen iktidarın kullanılmasıyla ilgili olarak da korumuştur. Nitekim, "kemer sıkma" tedbirleri çerçevesinde çıkarılan hakimlerin maaşlarıyla ilgili bir kanunu iptal eden kararında Mahkeme halkın egemenliğinin anayasal iktidarın bütün kolları (yasama, yürütme ve yargı) tarafından kullanıldığını belirtmiştir. $\mathrm{Bu}$ nedenle, yalnız başına parlamentonun iradesi halkın iradesinin en yüksek temsili olarak görülemez. Yargı bağımsızlığı ilkesi ise demokratik hukuk devletinin temel direklerinden biridir. Sonuç olarak,

${ }^{68}$ Priban 2002: 385; Bartole 2002: 426.

${ }^{69}$ Aktaran Priban 2002: 386.

${ }^{70}$ Prochazka 2002: 160. 
Anayasa Mahkemesi hakimleri bu kanuna dahil etmenin anayasaya aykırı olduğuna karar verdi. Bununla beraber, parlamento kanunda 1srar etti ve aynı kanunu ilk haliyle tekrar kabul etti ${ }^{71}$.

Ayrıca, 2001 y1lındaki bir kararında da Mahkeme halk iradesinin adil temsilini gözetmediği gerekçesiyle seçim kanununu iptal etmek suretiyle, yasama faaliyetine normatif sınırlar getirmiştir ${ }^{72}$.

Son olarak, Çek Anayasa Mahkemesi'nin "piyasa yanlısı aktivizmi”ne değinmek gerekir. Çek Anayasa Mahkemesi daima piyasa yanlısı olmuştur. Esasen, Mahkeme'nin "korumacılığın kalıntılarını bertaraf etme konusunda gösterdiği isteklilik onun geçiş dönemi içtihadının önemli bir unsurudur." Mahkeme'nin, “Zorla Çalıştırmanın Kaldırılmasına İlişkin ILO Sözleşmesi”ni ele alış biçimi bu bakış açısından kaynaklanmıştır. Nitekim, kadınların gece çalıştırılması hakkındaki yasal yasağın kaldırılmasının anayasaya uygunluğunu incelediği davada, Mahkeme ILO Sözleşmesi'ni insan haklarıyla ilgili bir antlaşma olarak değil de sadece kadınların çalıştırılmasına uygulanacak şartlar hakkındaki bir antlaşma olarak görmüştür ${ }^{73}$.

\section{V.SON DEĞERLENDİRMELER}

$\mathrm{Bu}$ çalışmada içtihadi eğilimleri gözden geçirilen yeni anayasa mahkemelerinin hepsinin de değişken derecelerde müdahaleci (aktivist) oldukları görülmektedir. Bu durum ele alınması gereken başlıca iki sorun ortaya çıkarmaktadır. Her şeyden önce, bu yeni mahkemelerin kendi ülkelerinde demokrasinin pekişmesine katkıda bulunup bulunmadıkları sorununun gözden geçirilmesi gerekmektedir. Ancak bundan önce, yeni kurulan demokrasilerde anayasa mahkemelerinin rolüne ihtiyatla yaklaşan bir görüşü hatırlamamız gerekiyor.

Stephen Holmes daha önce zikredilen nispeten erken bir makalesinde ${ }^{74}$, özellikle parlamentoların saygınlığının zayıflaması pahasına müdahaleci bir tutum izleyen mahkemelerin demokrasi inşasının ihtiyaçlarına uygun olmadığını ileri sürmüştür. Ona göre, bir anayasa mahkemesinin parlamentonun kabul ettiği kanunları sıkça iptal etmesi, kuvvetle muhtemeldir ki, yasama organının ve demokratik çoğunlukçuluğun meşruluğuna zarar verir. Oysa, meşruluğu tanınan yerleşik bir parlamento ve çoğunluk yönetimine saygi olmadan, Orta ve Doğu Avrupa'da olduğu gibi uygun olmayan bir zeminde demokratik bir rejimi kurmak imkansızdır. Bundan dolayı, anayasa yapımında güçlü bir yarg1 denetiminin öne

\footnotetext{
${ }^{71}$ Priban 2002: 387-388.

${ }^{72}$ Priban 2002: 390-91.

${ }^{73}$ Prochazka 2002: 155, 142.

${ }^{74}$ Holmes 1993.
} 
çıkarılması ve buna bağlı olarak anayasa mahkemelerinin siyaset yapımına aşırı müdahale etmeleri demokrasi kurma amacını baltalar. Onun için, yeni demokrasilerin ilk ihtiyacı anayasa mahkemeleri ve anayasa yargısı değildir, onların öncelikle yerleşik parlamentolara ihtiyacı vardır.

$\mathrm{Bu}$ tezde hatırı sayılır derecede doğruluk payı bulunduğu kanaatindeyim. Şüphesiz, J. S. Mill ve de Tocqueville'den buyana liberal düşünürler bize çoğunlukçuluğun tehlikelerini (dolayısıyla da çoğunluğu frenleme mekanizmalarının önemini) hatırlatmakta haksız değildirler; ama bundan Holmes'un uyarılarının büsbütün temelsiz olduğu sonucu çıkmaz. Çünkü, kuruluş aşamasındaki demokrasilerde, çoğunluk yönetiminin kendisi parlamenter kurumlar ve usullerde müesses hale gelmeden ve halkın gözünde meşruluk ve saygınlık kazanmadan demokrasinin "aşırılıkları"ndan söz etmek anlamlı olmayabilir. O bakımdan, çoğunluk yönetiminin daha kurumlaşma süreci içinde olduğu yerlerde eğer yargısal bir merci mütecaviz/müdahaleci kararlarıla parlamentonun halkın gözündeki saygınlığını azaltırsa, bu orada demokrasinin kurulma ve pekişme şansını ciddi olarak zayıflatabilir.

Şu halde, müdahaleci veya aktivist bir anayasa yargısı her zaman istenir bir şey olmadığı gibi, onun demokratikleşmeye katkı yapacağı da kesin değildir. Mamafih, burada müdahaleci yargının iki türü arasında ayrım yapmak gerekir. "Gerçek müdahalecilik" olarak adlandıracağım ilkinde, yarg1 denetimiyle görevli olan organ dar anlamda "anayasaya uygunluk" denetimi yapmanın ötesine geçerek, doğrudan doğruya politik-ideolojik kararlar verir. $\mathrm{Bu}$, yargının -özel olarak anayasa yargısının- verdiği kararlarla doğrudan doğruya yöneten çoğunluğun siyaset tercihlerini etkisiz kılmasıyla ilgilidir. $\mathrm{Bu}$, anayasa yargıçlarının kendilerini hukukçu olmaktan ziyade politik aktörler olarak algılamalarından kaynaklanabilir. Kanaatimce, anayasa mahkemelerinin bu türden müdahaleciliğinin meşruluğu sadece demokrasi inşası bakımından değil, fakat yerleşik demokrasiler açısından da şüphelidir. Bu bir tür "yargının siyasallaşması"dır ve böyle bir yönelim bizatihi anayasa mahkemesinin meşruluğunu baltalayabileceği gibi, genel olarak demokratik müzakerenin önemini de azaltabilir ${ }^{75}$. Mamafih, demokrasiye geçmenin aynı zamanda siyasi kültürün de az veya çok dönüşümünü gerektirdiği yerlerde, liberal-demokratik siyasal değerleri öne çıkaran bir yargısal aktivizmin demokratikleşmeye katkıda bulunabileceğini de gözden uzak tutmamak gerekir. Nitekim, yukarıda incelenen örneklerde anayasa mahkemelerinin demokrasinin yerleşmesine bu türden katkılar yaptıkları görülmektedir.

\footnotetext{
${ }^{75}$ Yargının siyasallaşması bazan da bütün politik uyuşmazlıkların çözümlerinin eninde sonunda hukukta ve anayasada bulunabileceği düşüncesinin bir sonucu olarak ortaya çıkar: Loughlin 2000: 194.
} 
Buna karș1lık, müdahaleci yargının şimdi belirteceğim ikinci türü Holmes'cü kaygıya yer bırakmayabilir. Burada Anayasa Mahkemesinin, belirli bir siyaset yönelimini kayırmaksızın, devletin politik organlarını anayasal sınırları içinde tutma istekliliği söz konusudur. Bunun pratik sonucu, anayasa yargısının bir yandan anayasanın "yetki haritası"nın politik organlar tarafindan zorlanmasını, öbür yandan da başta yasama ve yürütme olmak üzere kamu otoritelerinin kişilerin sivil hayat alanına keyfi müdahalesini ve genel hukuk güvencelerini tahrip etmesini önlemesidir. Başka bir ifadeyle, anayasa mahkemeleri yargısal işlevin sınırlarını kabul edip onlara riayet ederek, hala demokratik hukuk devleti idealine hizmet edebilirler. Sanırım, Macaristan, Polonya ve Çek anayasa mahkemelerinin kendi kısa tarihlerinde yaptıkları da esas olarak budur. Nitekim, onlar bir yandan ülkelerinin hukuk sitemlerinin _ "eski rejim"in özelliğinden kaynaklanan- eksiklerini telafi ederek, öbür yandan onları ileri anayasal demokrasilerin düzeyine çıkarmak için kavramlar geliştirerek veya inşa ederek hukuka bağlı yönetim ilkesinin yerleşmesine katkı yapmışlardır. Ve bu işi başarırken "(b)u mahkemelerin, anayasal olarak tanınmış sınırlara riayet etmeleri ve anayasanın tanımladığı standartlar içinde çalıșmaları bakımından, biçimsel ve kurumsal anlamda bir meşruluk sorunları" olmamış olması bir şanstır. Bunda, onların, "anayasalarının, anayasa mahkemeleri kuruluş yasalarının veya yetkilerini belirleyen diğer ilgili yasaların kendilerine gösterdikleri sınırları aşmama"ya ${ }^{76}$ özen göstermiş olmaları şüphesiz etkili olmuştur.

İncelenen anayasa mahnkemelerinin performanslarının değerlendirilmesiyle ilgili ikinci önemli nokta, bu mahkemelerin yerine getirdikleri işlevi genellikle bu iş için pek elverişli olmayan bir zeminde başarmış olmalarıdır. Oysa, normal olarak böyle bir sonucun beklenmemesi gerekirdi. Yani, hukukun üstünlüğü, yargı bağımsızlığı ve insan haklarına ilişkin doktriner ve pratik geleneklerin zayıf olduğu bir toplumda anayasa mahkemesinin başarılı olma ihtimalinin zayıf olduğu varsayılır. Nitekim, Klaus von Beyme "(y)argısal denetim(in) en etkili ve yoğun olarak, Rechtsstaat'1n demokrasinin doğumundan önce yerleşmiş olduğu sistemlerde işle"diğini ${ }^{77}$ belirtmektedir. Gelgelelim, diğer komünizm-sonrası ülkeler gibi, burada ele alınan ülkelerde de yargı bağımsızlığı dahil hukuk devleti gelenekleri ya yoktu ya da çok zayıftı ${ }^{78}$. Komünist rejim hukuk devleti yönündeki komünizmden önceki kurumsal ve tutumsal çabaların kalıntılarını bile yok etmişti. Şu halde, von Beyme'nin öngörüsünün bu ülkelerin gerçeklerine uygun düşmediğini söyleyebiliriz. $\mathrm{Bu}$ durumun $\mathrm{k} 1 \mathrm{smi}$ bir istisnası Macaristan'ın durumudur. Bu ülkede "yargı(nın) kapsamlı bir geleneksel

\footnotetext{
${ }^{76}$ Sadurski 2000, "Legitimacy...": 165.

${ }^{77}$ Nakleden Sadurski 2002, “Legitimacy....” 164.

${ }^{78}$ Herron \& Randazzo 2002.
} 
hukuka dayanması"79 Macaristan Anayasa Mahkemesi'nin yazılı hukuka direnmesini teşvik etmiş olabilir.

Sonuç olarak, başlıkta koyduğum soruya şöyle cevap verebilirim: Evet, demokrasilerin kurulması ve yerleşmesinde anayasa mahkemeleri önemlidir, ama bazı kayıtlarla.

${ }^{79}$ Prochazka 2002: 50. 


\section{KAYNAKLAR}

Bartole, Sergio (2002), "Conclusions: Legitimacy of Constitutional Courts: Between Policy Making and Legal Science", in Sadurski (2002), pp. 409-32.

Brunner, Georg, "Structure and Proceedings of Hungarian Constitutional Judiciary", in Solyom and Brunner 2000, pp. 65-102.

Epstein, Lee \& Knight, Jack \& Shvetsova, Olga (2001), "The Role of Constitutional Courts in the Establishment and Maintenance of Democratic Systems of Government", Law \& Society Review, Vol. 35, Issue 1, p. 117.

Erdoğan, Mustafa (2005), Anayasal Demokrasi (Ankara: Siyasal Kitabevi, 7. b.)

Garlicki, Leszek Lech, "The Experience of the Polish Constitutional Court", in Sadurski (2002), pp. 265-82.

Halmai, Gabor (2002), "The Hungarian Approach to Constitutional Review: The End of Activism? First Decade of the Hungarian Constitutional Court", in Sadurski (2002), pp. 189-211.

Herron, Erik S. \& Randazzo, Kirk A. (2003), "The Relationship Between Independence and Judicial Review in Post-Communist Courts", The Journal of Politics, Vol. 65, No. 2, May, pp. 422-38.

Holmes, Stephen (1993), "Back to the Drawing Board", East European Constitutional Review 2, No. 1, pp.21-25.

Howard, A. E. Dick (1993) (ed.), Constitution Making in Eastern Europe (Washington, D.C: The Woodrow Wilson Center Press).

Jacob, Herbert (1996), "Introduction", in Courts, Law, and Politics in Comparative Perspective (New Haven \& London: Yale University Press).

Linz, Juan J. \& Stepan Alfred (1996), "Toward Consolidated Democracies", Journal of Democracy, Vol. 7. No. 2, pp. 14-33

Loughlin, Martin (2000), Sword and Scales: An Examination of the Relationship Between Law and Politics (Oxford \& Portland: Hart Publishing).

Paczolay, Peter (1993), "The New Hungarian Constitutional State: Challenges and Perspectives", in Dick (1993), pp. 21-55.

Pederzoli, Patrizia \& Guarnieri, Carlo (1997), "Italy: A Case of Judicial Democracy?", International Social Science Journal, June 97, Volume 49, Issue 2, p. 253. 
Priban, Jiri (2002), "Judicial Power vs. Democratic Representation: The Culture of Constitutionalism and Human Rights in the Czech Legal System", in Sadurski (2002), pp. 373-94.

Prochazka, Radoslav (2002), Mission Accomplished: On Founding Constitutional Adjudication in Central Europe (Budapest \& New York: Central European University Press).

Sadurski, Wojciech (2002), "Legitimacy and Reasons of Constitutional Review after Communism" in Sadurski (2002), pp. 163-87.

Sadurski, Wojciech (2002) (ed.), Constitutional Justice, East and West (The Hauge \& London \& New York: Kluwer Law International)

Schedler, Andreas \& Diamond, Larry \& Plattner, Marc F. (1999) (eds.), The Self- Restraining State: Power and Accountability in New Democracies (Boulder/Co. and London: Lynne Rienner Publishers)

Schwartz, Herman (2000), The Struggle for Constitutional Justice in PostCommunist Europe (Chicago and London: university of Chicago Press).

Schwartz, Herman (1999), "Surprising Success: The New Eastern European Constitutional Courts", in Schedler \& Diamond \& Plattner, pp. 195214.

Solyom, Laszlo \& Brunner, Georg (2000), Constitutional Judiciary in a New Democracy: The Hungarian Constitutional Court (Ann Arbor: The University of Michigan Press).

Tate, C. Neal (1995), "Why the Expansion of Judicial Power?" in C. N. Tate \& T. Vallinder, eds. The Global Expansion of Judicial Power (New York: New York University Press) 